\title{
Eolian dust dispersal patterns since the last glacial period in eastern Central Asia: insights from a loess-paleosol sequence in the Ili Basin
}

\author{
Yue Li ${ }^{1,2,3}$, Yougui Song ${ }^{1}$, Kathryn E. Fitzsimmons ${ }^{2}$, Hong Chang ${ }^{1}$, Rustam Orozbaev $^{4,5}$, and Xinxin $\mathbf{L i}^{1}$ \\ ${ }^{1}$ State Key Laboratory of Loess and Quaternary Geology, Institute of Earth Environment, Chinese Academy of Sciences, \\ Xi'an, 710061, China \\ ${ }^{2}$ Research Group for Terrestrial Palaeoclimates, Max Planck Institute for Chemistry, Mainz, 55128, Germany \\ ${ }^{3}$ College of Earth Science, University of Chinese Academy of Sciences, Beijing, 100049, China \\ ${ }^{4}$ Institute of Geology, National Academy of Sciences of Kyrgyz Republic, Bishkek, 720040, Kyrgyzstan \\ ${ }^{5}$ Research Center for Ecology and Environment of Central Asia, Chinese Academy of Sciences, Ürümqi, 830011, China
}

Correspondence: Yougui Song (syg@ieecas.cn)

Received: 19 March 2017 - Discussion started: 27 March 2017

Revised: 18 November 2017 - Accepted: 22 January 2018 - Published: 6 March 2018

\begin{abstract}
The extensive loess deposits of the Eurasian midlatitudes provide important terrestrial archives of Quaternary climatic change. As yet, however, loess records in Central Asia are poorly understood. Here we investigate the grain size and magnetic characteristics of loess from the Nilka (NLK) section in the Ili Basin of eastern Central Asia. Weak pedogenesis suggested by frequency-dependent magnetic susceptibility $\left(\chi_{\mathrm{fd}} \%\right)$ and magnetic susceptibility (MS) peaks in primary loess suggest that MS is more strongly influenced by allogenetic magnetic minerals than pedogenesis, and may therefore be used to indicate wind strength. This is supported by the close correlation between variations in MS and proportions of the sand-sized fraction. To further explore the temporal variability in dust transport patterns, we identified three grain size end-members (EM1, mode size $47.5 \mu \mathrm{m}$; EM2, $33.6 \mu \mathrm{m}$; EM3, $18.9 \mu \mathrm{m}$ ) which represent distinct aerodynamic environments. EM1 and EM2 are inferred to represent grain size fractions transported from proximal sources in short-term, near-surface suspension during dust outbreaks. EM3 appears to represent a continuous background dust fraction under non-dust storm conditions. Of the three end-members, EM1 is most likely the most sensitive recorder of wind strength. We compare our EM1 proportions with mean grain size from the Jingyuan section in the Chinese loess plateau, and assess these in the context of modern and Holocene climate data. Our research suggests that the Siberian High pressure system is the dominant influence on
\end{abstract}

wind dynamics, resulting in loess deposition in the eastern Ili Basin. Six millennial-scale cooling (Heinrich) events can be identified in the NLK loess records. Our grain size data support the hypothesis that the Siberian High acts as teleconnection between the climatic systems of the North Atlantic and East Asia in the high northern latitudes, but not for the mid-latitude westerlies.

\section{Introduction}

Central Eurasia experiences extremely continental climatic conditions, in large part due to its position far from the oceans. Arid Central Asia (ACA), the mid-latitude region spanning the Caspian Sea across to the eastern Tian Shan mountains, is therefore a sensitive recorder of past climate change due to its location in the transitional region between the Asian monsoons (Cheng et al., 2012; Dettman et al., 2001), mid-latitude westerlies (Vandenberghe et al., 2006), and the North Asian polar front (Machalett et al., 2008). The relative importance and intensity of these major climate subsystems has varied across the latitudinal and longitudinal range of Central Asia through time. Thus, identification of the predominant climate regimes in this region, using geological archives, is a crucial precondition for tracing paleoclimatic evolution. 
One of the most promising potential palaeoenvironmental archives in ACA is its widespread, thick loess deposits. Loess is one of the most important archives of Quaternary climate change (Maher, 2016; Muhs, 2013). In Central Asia, the loess deposits drape the piedmont slopes of the major mountain ranges - the Tian Shan, Alai, Altai, and Pamirs, from the Xinjiang province in China (Fang et al., 2002; Li et al., 2016, 2015; Liu, 1985; Song et al., 2014, 2012) through Kazakhstan (Feng et al., 2011; Fitzsimmons et al., 2016; Machalett et al., 2006, 2008), Kyrgyzstan (Youn et al., 2014), and Uzbekistan (Smalley et al., 2006), and into Tajikistan (Dodonov et al., 2006; Li et al., 2016b; Yang et al., 2006). While recent years have witnessed increasing loessbased datasets in the region, the forcing mechanisms and the climatic conditions responsible for loess-paleosol sequences formation are as yet not systematically understood (Fitzsimmons et al., 2016; Li et al., 2016, 2017; Machalett et al., 2008; Song et al., 2018a, b).

Evidence for millennial-scale climatic oscillations associated with Greenland (Dansgaard-Oeschger, or (D-O) events) (Dansgaard et al., 1993) and cool phases associated with iceberg calving into the North Atlantic (Heinrich $(\mathrm{H})$ events) (Bond et al., 1992) has been found in the form of grain size variations in loess deposits in the Chinese Loess Plateau (CLP) (Chen et al., 1997; Porter and An, 1995; Sun et al., 2012) and Europe (Antoine et al., 2009; Rousseau et al., 2007; Zeeden et al., 2016). Data for Central Asian loess do not as yet exist at this resolution, despite its strategic location as a likely environmental bridge between the North Atlantic and East Asian Monsoon climatic regions (Li et al., 2016a; Song et al., 2018a).

The Ili Basin of Central Asia hosts thick loess deposits in the strategic central eastern part of ACA (Song et al., 2014). The basin is surrounded to the south and north by the Tian Shan mountain range, widens to the west and drains into the endorheic basin of Lake Balkhash (Fig. 1), and provides a conducive situation for loess accumulation (Feng et al., 2011; Jia et al., 2012; Li et al., 2016a; Song et al., 2017, 2010). In this paper we present new data on the physical properties of a $20.5 \mathrm{~m}$ thick loess deposit at NLK in the eastern Ili Basin. We investigate variations in grain size distributions and magnetic properties in order to explore likely links with environmental dynamics.

\section{Physical geography}

The Ili Basin $\left(78-85^{\circ} \mathrm{E}\right.$ and $\left.42^{\circ} 30^{\prime}-44^{\circ} 30^{\prime} \mathrm{N}\right)$ straddles southeast Kazakhstan and northwest China. It is an intermontane basin opening westward towards the Ili drains into Lake Balkhash which is in the semi-arid transitional region between the steppe and full deserts of Central Asia. The northern and southern Tian Shan form the northern and southern margins of the basin (Fig. 1a).
This region has a semi-arid, continental climate, with a strong precipitation gradient dependent on altitude. The altitude of the basin floor is $500-780 \mathrm{~m}$; the northern Tian Shan reaches altitudes of $>4000 \mathrm{~m}$ a.s.l. and the southern Tian Shan ranges between 3000 and $7000 \mathrm{~m}$ a.s.l. towards the catchment divide. Mean annual precipitation (MAP) ranges between 200 and $500 \mathrm{~mm}$ on the plains, but can reach $1000 \mathrm{~mm}$ in the mountain zones, and mean annual temperature (MAT) ranges from 2.6 to $10.4{ }^{\circ} \mathrm{C}$ (Li, 1991). Modern meteorological data (2009-2013) show a MAP of $354 \mathrm{~mm}$ and a MAT of $7.3{ }^{\circ} \mathrm{C}$ in Nilka site (data from the China Meteorological Data Network: http://data.cma.cn/). The surface vegetation in this region is dominated by steppe and desert steppe and the zonal soils comprised of sierozem, castonozem, and chernozem.

\section{Materials and methods}

\subsection{Section and sampling}

The NLK section $\left(83.25^{\circ} \mathrm{E}, 43.76^{\circ} \mathrm{N} ; 1253 \mathrm{~m}\right.$ a.s.1.) is situated on the second terrace of the right bank of the Kashi River, a tributary of the Ili River. The site is located in the eastern Ili Basin of far western China, adjoining the northern Tian Shan to the north (Fig. 1b). The section has a thickness of $20.5 \mathrm{~m}$ and overlies fluvial sands and gravels (Fig. 1c). The profile has been exposed by local residents for making bricks, and recently formed the focus of a geochronological study comparing luminescence with radiocarbon methods (Song et al., 2015). According to the dating results, the NLK loess started to accumulate $\sim 70 \mathrm{ka}$ ago. Stratigraphically and geochronologically, the loess package at NLK is equivalent to the L1 loess unit (also known as Malan loess) and S0 paleosol unit (known as Holocene Heilu soil) in the CLP (Liu, 1985). Although largely homogeneous in appearance, two weak paleosols (at depths ranging from 5.0-7.0 m and $15.7-18.0 \mathrm{~m}$ ) were identified in the section by field observations. We therefore divided the NLK stratigraphy into S0, L1L1, L1S1, L1L2, L1S2 and L1L3 units (Fig. 1c).

After cleaning the NLK section to remove dry, weathered sediment, samples were collected at intervals of $2 \mathrm{~cm}$. A total of 1026 bulk samples were prepared for measurements of physical characteristics. Because optically stimulated luminescence (OSL) dating is more reliable for constructing a loess chronology than bulk sediment AMS ${ }^{14} \mathrm{C}$ dates (Song et al., 2015), this study uses the previously published OSL dating results as the basis for our age model.

\subsection{Grain size analyses}

Prior to grain size measurements, $0.5 \mathrm{~g}$ of dry bulk sample was pretreated by the removal of organic matter and carbonate using $\mathrm{H}_{2} \mathrm{O}_{2}$ and $\mathrm{HCl}$, respectively ( $\mathrm{Lu}$ and An, 1997). Samples were then dispersed in an ultrasonic bath for $5 \mathrm{~min}$ with $10 \mathrm{~mL} 10 \%\left(\mathrm{NaPO}_{3}\right)_{6}$ solution. Grain size distribution 


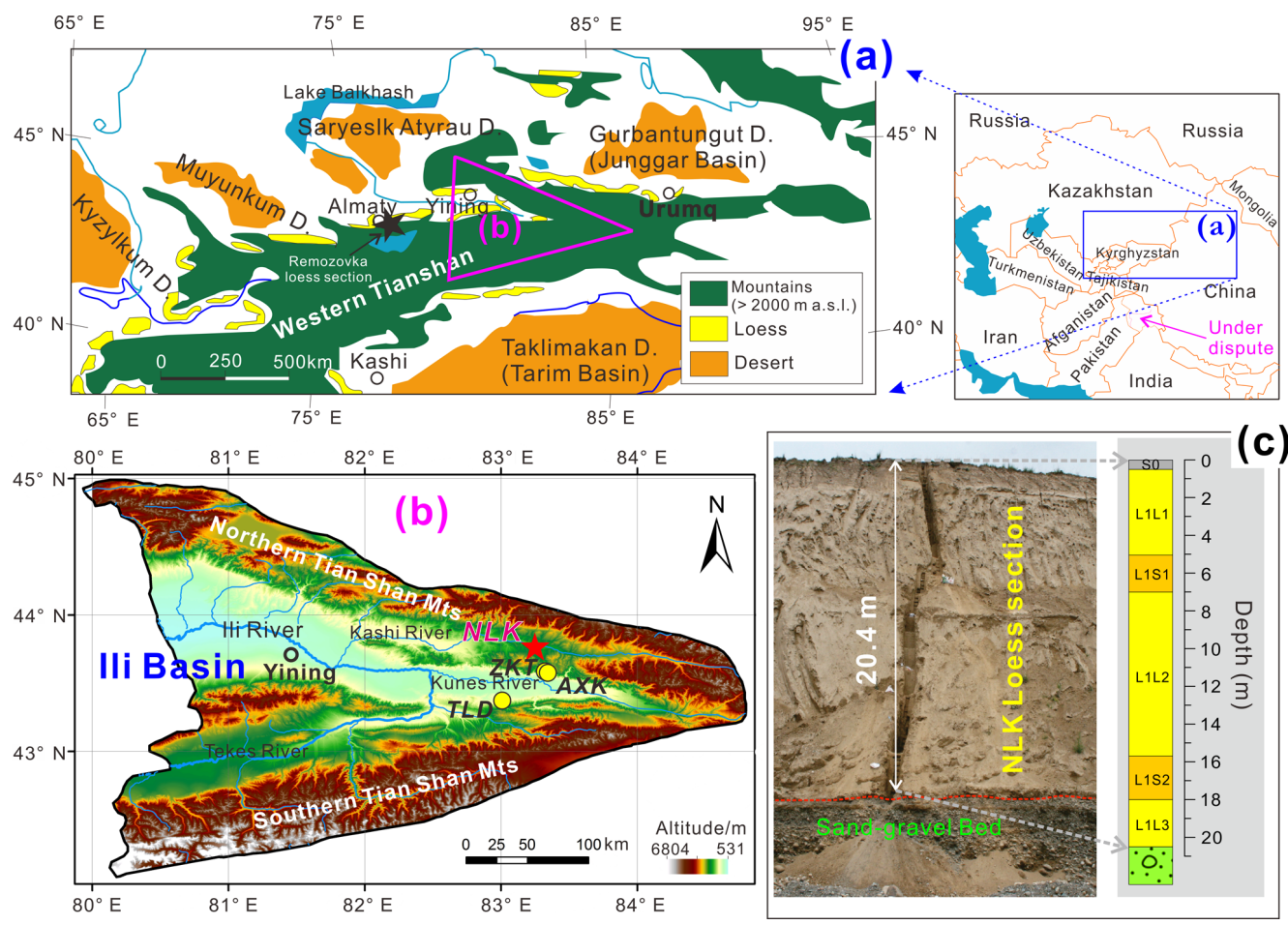

Figure 1. The location of study area and the photo of the Nilka (NLK) section.

was analyzed using a Malvern 2000 laser instrument at the State Key Laboratory of Loess and Quaternary Geology, Institute of Earth Environment, Chinese Academy of Sciences. Particle size distribution was calculated for 100 grain size classes within a measuring range of $0.02-2000 \mu \mathrm{m}$. Replicate analyses indicated an analytical error of $<2 \%$ for the mean grain size.

End-member unmixing of loess grain size distributions is based on the hierarchical Bayesian model for end-member modeling analysis (BEMMA; Yu et al., 2016). Grain size parameters were calculated from the analytical data with the grain size distribution and statistics (GRADISTAT) package (Version 4.0; Blott and Pye, 2001).

Two samples, NLK1106 at $11.06 \mathrm{~m}$ and NLK1840 at $17.8 \mathrm{~m}$, were also selected for the extraction and measurement of mineral-specific quartz grain size according to published methods (Sun et al., 2000). The isolated quartz grain samples (Fig. S1 in the Supplement) were then analyzed by the Malvern 2000 laser instrument so that comparisons of quartz grain and bulk samples could be performed to investigate the weathering degree of NLK loess.

\subsection{Magnetic susceptibility measurements}

Magnetic susceptibility was measured with a Bartington MS2 meter at the State Key laboratory of Loess and Quaternary Geology, Institute of Earth Environment, Chinese Academy of Sciences. Samples were oven dried at $40^{\circ} \mathrm{C}$ for $24 \mathrm{~h}$. Subsamples of $10 \mathrm{~g}$ from each sample were then pre- cisely weighed for magnetic measurements. Low-frequency $(0.47 \mathrm{kHz})$ and high-frequency $(4.7 \mathrm{kHz})$ magnetic susceptibility ( $\chi_{\mathrm{lf}}$ and $\chi_{\mathrm{hf}}$, respectively) were measured. The absolute frequency-dependent magnetic susceptibility was calculated as $\chi_{\mathrm{fd}}=\chi_{\mathrm{lf}}-\chi_{\mathrm{hf}}$. Frequency-dependent magnetic susceptibility was defined and calculated as $\chi_{\mathrm{fd}} \%=\left[\left(\chi_{\mathrm{lf}}-\chi_{\mathrm{hf}}\right) / \chi_{\mathrm{lf}}\right] \times$ $100 \%$.

\section{Results}

\subsection{Magnetic susceptibility variations}

Both magnetic susceptibility (MS) data and stratigraphy show a close correspondence throughout the NLK section. We observe higher MS values within primary loess and lower values within paleosols. The exception to this trend is the modern (S0) soil which yields high MS values (Fig. 2).

The $\chi_{\text {If }}$ values of the S0 unit are higher than the values for the L1 unit, with an average of $98.13 \times 10^{-8} \mathrm{~m}^{3} \mathrm{~kg}^{-1}$. The $\chi_{\text {If }}$ values of the L1L1 unit vary from 56.5 to $103.9 \times$ $10^{-8} \mathrm{~m}^{3} \mathrm{~kg}^{-1}$, decreasing the down profile. The $\chi_{\text {If }}$ value abruptly decreases at ca. $5 \mathrm{~m}$, with generally lower values in the L1S1 unit, averaging $62.58 \times 10^{-8} \mathrm{~m}^{3} \mathrm{~kg}^{-1} \cdot \chi_{\mathrm{lf}}$ in the L1L2 unit gradually increases the down profile, with significant fluctuations in the lower part; $\chi_{\text {lf }}$ values vary from 67 to $102.55 \times 10^{-8} \mathrm{~m}^{3} \mathrm{~kg}^{-1}$. Lower $\chi_{\text {If }}$ values are observed in L1S1 unit with an average value of $57.99 \times 10^{-8} \mathrm{~m}^{3} \mathrm{~kg}^{-1}$. In the L1L3 unit, the $\chi_{\text {lf }}$ values vary with greater amplitude around an average value of $68.74 \times 10^{-8} \mathrm{~m}^{3} \mathrm{~kg}^{-1}$. 


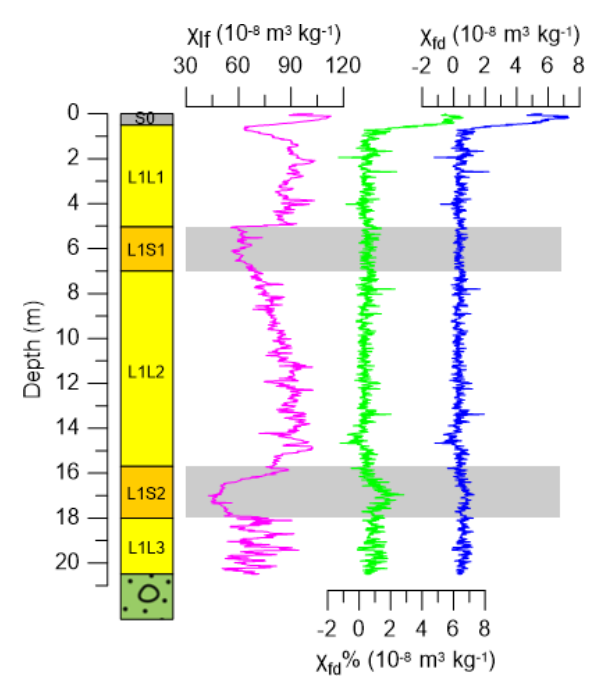

Figure 2. Lithology and magnetic susceptibility characteristics $\left(\chi_{\mathrm{lf}}, \chi_{\mathrm{fd}}\right.$ and $\left.\chi_{\mathrm{fd}} \%\right)$ of the NLK section.

Absolute frequency-dependent magnetic susceptibility $\left(\chi_{\mathrm{fd}}\right)$ values likewise vary with stratigraphy. The S0 unit yields the highest $\chi_{\mathrm{fd}}$ value. The L1 unit is characterized by relatively consistent and lower $\chi_{\mathrm{fd}}$ values. Frequencydependent magnetic susceptibility $\left(\chi_{\mathrm{fd}} \%\right)$ yields the same trend as $\chi_{\mathrm{fd}}$, although $\chi_{\mathrm{fd}} \%$ values clearly increase in the central part of L1S2.

\subsection{Mixing model of loess grain size distributions}

The mean grain size distribution, and variation range of volume frequencies for each grain size class in the dataset, are presented in Fig. 3a. The overall grain size frequency curve shows a unimodal pattern, slightly skewed towards the coarser side, with the primary mode ranging from 11.9 to $47.5 \mu \mathrm{m}$. An additional small grain size peak occurs at ca. 0.4-2 $\mu \mathrm{m}$. Three unmixed end-members were identified (Fig. S2), yielding fine-skewed grain size distributions with clearly defined modes of $47.5 \mu \mathrm{m}$ (EM1), $33.6 \mu \mathrm{m}$ (EM2) and $18.9 \mu \mathrm{m}$ (EM3) (Fig. 3b).

The proportional distribution of the end-members down the section is shown in Fig. 4. In the primary loess units (L1L1, L1L2 and L1L3), the deposits are dominated by the coarser silt EM1 and EM2, while higher proportions of fine silt EM3 are observed within the soil horizons (S0, L1S1 and L1S2). EM1 displays high-frequency and large-amplitude fluctuations in the down profile, varying between 0.09 and 0.72 , and clearly dominates the primary loess units and occurs in low proportions in the soil units (Fig. 4). EM2 shows a similar trend to EM1, but with less variability in the down profile. Proportions of EM2 range between 0.11 and 0.66 with minimal fluctuations within individual units, and proportions decrease significantly in the soil units S0 and L1S2. Proportions of EM3 remain consistently low within the pri- mary loess units, and increase to 0.46 and 0.8 within soil horizons S0 and L1S2 respectively.

\section{Discussion}

\subsection{Impacts of wind strength on magnetic susceptibility variations}

Magnetic susceptibility (MS) in loess is predominantly determined by the concentration of iron-bearing magnetic minerals within the sediment (Liu et al., 1999, 1994; Song et al., 2010). Generally, this varies between primary loess and soil horizons. Soils generally experience an enrichment in magnetic minerals (higher MS), in comparison to the primary loess (Buggle et al., 2009; Ding et al., 2002; Heller and Evans, 1995; Heller and Liu, 1984; Maher and Thompson, 1992; Zhou et al., 1990).

The contrast between high and low MS in paleosols and primary loess, respectively, typically forms the basis for the stratigraphic differentiation of loess deposits. The main MS variations in the NLK loess sequence, with the exception of the S0 unit, however, do not follow this trend (Fig. 2). At NLK, lower MS values are found in the paleosols and higher MS in loess units. A similar case also occurs in the L1 loess layers at other sites in the Ili Valley, such as the Talede (TLD), Zeketai (ZKT), and Axike (AXK) sections (Fig. 1) (Jia et al., 2012, 2010; Song et al., 2010).

$\chi_{\mathrm{fd}}$ indicates the concentration of magnetic particles within a small grain size range across the superparamagnetic (SP)/stable single domain (SSD) boundary (Liu et al., 2012) (magnetite, $<\sim 100 \mathrm{~nm}$; maghemite, $<\sim 20 \mu \mathrm{m}$ ). Particles with this grain size are considered to form in situ within soils during pedogenesis (Maher and Taylor, 1988; Zhou et al., 1990). Therefore, $\chi_{\mathrm{fd}}$ can serve as a direct proxy for pedogenesis (Buggle et al., 2014; Heller et al., 1993; Liu et al., 2007). In the NLK section, $\chi_{\mathrm{fd}}$ yields consistently low values throughout the sequence and indicates no clear enrichment even in paleosol layers L1S1 and L1S2. Comparison between $\chi_{\text {lf }}$ vs. $\chi_{\mathrm{fd}}$ down profile shows no correlation between MS and SP particles (Fig. S3c). These results suggest that SP particles played only a minor role in MS enhancement in NLK loess.

$\chi_{\mathrm{fd}} \%$ is used as a proxy to determine the contribution of SP particles to MS (Liu et al., 1992; Zhou et al., 1990). At the NLK section, however, we also observe consistently low $\chi_{\mathrm{fd}} \%$ values in both loess and paleosol layers, with a slight increase only in the L1S1 paleosol. This observation reinforces our interpretation that the content of SP particles is very low, and consequently that their contribution to MS can be ignored.

The low proportions of SP particles in the NLK loess imply that the pseudo-single-domain (PSD) and multi-domain (MD) magnetic grains, rather than SP grains forming in situ, are more influential for the magnetic enhancement at this site. Since PSD and MD magnetic minerals are difficult to pro- 

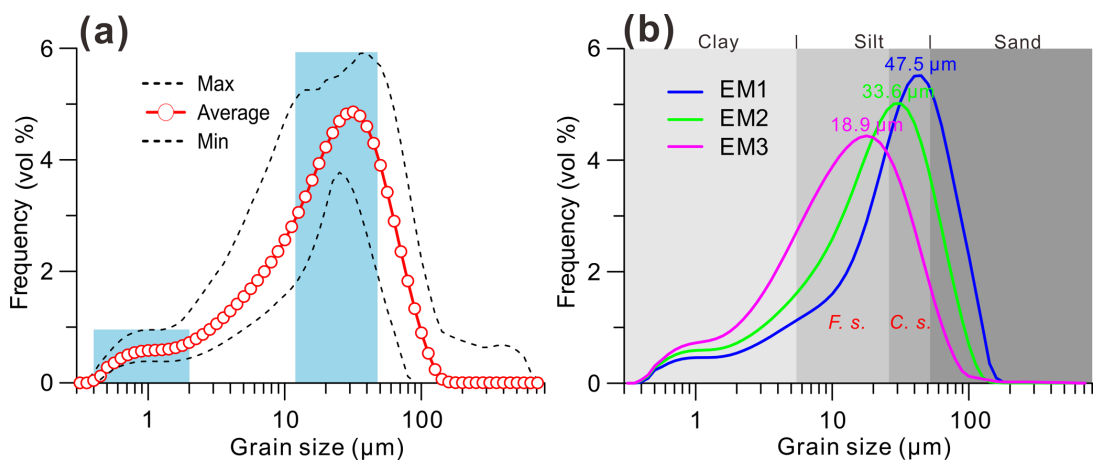

Figure 3. End-member modeling results of the grain size dataset of the NLK section. (a) Mean size distribution and range of volume frequency for each size class. (b) Modeled end-members according to the three-end-member model (modal sizes: $\sim 47.5, \sim 33.6$ and $\sim 18.9 \mu$ m). Size limits of clay, silt and sand fractions determined by laser particle sizer differ from those derived by the pipette method. The upper limits of grain size classes used here are at 4.6 / $5.5 \mu \mathrm{m}$ for clay, $26 \mu \mathrm{m}$ for fine silt, and $52 \mu \mathrm{m}$ for coarse silt, as previously published by Konert and Vandenberghe (1997). Sand is designated for particle sizes $>52 \mu \mathrm{m}$. Therefore, EM1 and EM2 correspond to coarse silt and EM3 to fine silt.

duce during pedogenesis (Song et al., 2010), such minerals are more likely to be detrital in nature and are derived from the original protolith.

In some cases, moist conditions associated with pedogenesis may result in the weathering and dissolution of the magnetic minerals maghemite and magnetite (Grimley and Arruda, 2007; Maher, 1998; Nawrocki et al., 1996). In such cases, a negative relationship between magnetic susceptibility and pedogenesis can develop, which is in contrast to the classical situation whereby $\chi_{\mathrm{fd}}$ is enhanced. At the NLK section, however, we observe no textures caused by groundwater fluctuations. We therefore exclude groundwater fluctuations and high levels of precipitation as a factor in our MS characteristics at the NLK section.

In the wind velocity/vigor model (also known as the Alaskan or Siberian model), wind strength affects MS values of loess through the physical sorting of magnetic grains (Beget and Hawkins, 1989). The influence of this process on MS values in loess can be assessed by investigating the correlation between MS and coarser (silt or sand) and finer clay percentages (Fig. S3). At NLK, MS values in the S0 soil between 0 and $0.5 \mathrm{~m}$ correlate positively with clay percentage variations (Fig. S3a), while higher MS values at depths greater than $>0.5 \mathrm{~m}$ correlate closely with increased sand concentrations (Fig. S3b). We therefore propose that MS enhancement at NLK is likely driven by wind strength. Under this scenario, weak pedogenesis prevented the efficient production of SP grains (Fig. 2), and allogenetic magnetic minerals associated with dust transportation made a greater contribution to the MS. Wind strength can therefore be interpreted as the main influence on MS variations at NLK. The enhancement of magnetic susceptibility in NLK loess most likely falls into region A in Fig. 9 of Liu et al. (2013). Region A represents the area where the climate is arid, and pedogenesis is weak and dominated by physical weathering (Liu et al., 2013). Therefore, we can use the "wind theory" to decipher the MS variations of NLK loess. Weak pedogenesis enables preservation of primary atmospheric dust contributions to NLK.

\subsection{Genetic interpretations of end-members in loess grain size}

Grain size analysis was conducted in order to understand wind dynamics (strength and direction) during loess deposition (Liu, 1985; Lu and An, 1998; Sun et al., 2010). Grain size analysis provides information on sediment depositional mechanisms as well as insight into spatio-temporal changes in deposition. Provided factors such as vegetation, pedogenesis, grain size of source sediments, and distance from the deposition area to source area are also taken into account (Ding et al., 1999; DiPietro et al., 2017; Obreht et al., 2015; Qin et al., 2005; Terhorst et al., 2012; Yang and Ding, 2008).

Statistical analysis of loess grain size offers new opportunities for understanding paleoclimate variations. Studies increasingly use grain size partitioning to identify subpopulations within bulk samples. There are two dominant approaches to unmixing grain size spectra: parametric decomposition (e.g., Sun et al., 2002) and non-parametric decomposition (e.g., Prins and Vriend, 2007; Weltje, 1997; Weltje and Prins, 2007). Based on the statistical datasets generated, the different end-members can be interpreted to infer distinct atmospheric transport mechanisms, modes, and travel distances (Ujvari et al., 2016). In some cases, the end-member approach has been used to identify variation in the geological context or source area (Prins et al., 2007). We investigated the applicability of this approach to the Ili Basin loess at NLK by unmixing grain size distributions with BEMMA (Yu et al., 2016) and generating a mixing model consisting of three end-members (Fig. S2).

Relying largely on samples from the Eurasian loess belt extending from the Russian Plain north of the Caspian Sea eastwards to the Tibetan Plateau and CLP, Vanden- 
berghe (2013) applied the visual inspection of grain size distribution curves and EMMA end-member analysis to define the characteristic grain size distribution of primary loess deposits and interpret the likely conditions of transport and deposition. Using the sediment groups identified in Vandenberghe (2013), some studies interpreted multiple sources for loess sediments (Nottebaum et al., 2014, 2015; Yang et al., 2016). In this study, we apply the end-member analysis of NLK loess to the sediment groups of Vandenberghe (2013) in an effort to reconstruct dominant eolian processes.

Fine sand ("sediment type 1.a" in Vandenberghe, 2013) is a typical component of loess deposits near to or overlying river terraces. Although the NLK section lies on the second terrace of the Kashi River and therefore close to a potential source of coarsely grained material, the fine-sand end-member is completely absent. Modal grain sizes in this range (ca. $75 \mu \mathrm{m}$ ) are common in loess along the Huangshui and Yellow rivers in China (Prins et al., 2009; Vandenberghe et al., 2006; Vriend and Prins, 2005), the Danube and Tisza rivers in Serbia (Bokhorst et al., 2011), and the Mississippi valley in the USA (Jacobs et al., 2011). Since this fraction is interpreted to originate from proximal sources, the grain size of the available source material, rather than wind energy, plays a more important role in the presence and proportions of this grain size (Vandenberghe, 2013). The lack of fine sand at NLK may be attributed to three things: its location in the upper reaches of the Kashi River (Fig. 1b) in a region which lacks available supplies of fine sand, the V-shaped nature of the channel which is not conducive to eolian entrainment of bank deposits, and the relatively high altitude of NLK within the basin, which inhibits transport and deposition of coarser sediment grains (Vandenberghe, 2013).

The three members identified at NLK correspond to coarse silt (EM1 and EM2) and fine silt (EM3) (Fig. 3b). Each likely represents different kinds of depositional processes which operated throughout the accumulation of the deposit at NLK. Here we focus on the implications of these three end-members for understanding past environmental conditions responsible for loess-paleosol sequence formation.

EM1 has a modal grain size of $47.5 \mu \mathrm{m}$ (Fig. 3b), which approximately corresponds to the "subgroup 1.b.l" of Vandenberghe (2013). The mode is similar to end-members identified in loess from the CLP and north-eastern Tibetan Plateau (NE-TP) (EM2: $44 \mu \mathrm{m})$ (Vriend et al., 2011). The size of this component is unlikely to be due to longerdistance transport. Rather, it is inferred to derive from a shorter-distance transport of a suspended load (Vandenberghe, 2013; Vriend et al., 2011). Coarser particles $(>20 \mu \mathrm{m})$ rarely reach suspension above the near surface ( $0-200 \mathrm{~m}$ above the ground). When entrained by wind, they do not remain in suspension for long enough to travel long distances (Pye, 1987; Tsoar and Pye, 1987). Since the average grain size of EM1 is $26.74 \mu \mathrm{m}$ (calculated after Folk and Ward, 1957), we infer that this fraction was transported mainly during short-term suspension episodes at lower eleva- tions by surface winds, and deposited short distances downwind of the source. These short-term suspension episodes may correspond to spring and summer dust storms. Our interpretation is supported by present-day dust measurements on the CLP which identify a similar modal grain size during such events (Sun et al., 2003).

EM2 represents a mode at $33.6 \mu \mathrm{m}$ (Fig. 3b). It lies towards the finer end of the range of subgroup 1.b.2 (Vandenberghe, 2013). Comparable loess of the same grain size has been identified in loess from the northern Qilian Shan and the Hexi Corridor (EM2: $33 \mu \mathrm{m}$ ) in northern China, which was also interpreted as depositing from short-term suspension (Nottebaum et al., 2015). Loess of this grain size has been attributed to dust fallout (Muhs and Bettis, 2003; Pye, 1995) and fallout from low-altitude suspension clouds (Sun et al., 2003), as measured from modern depositional events. This fraction requires less wind energy than EM1, is transported further, is more widely distributed, and therefore comprises a higher proportion of distal loess populations (Vandenberghe, 2013). We propose that EM2 was transported mainly in short-term, near-surface suspension during dust storms, and that wind strength controlled the relative proportions of EM1 and EM2 through time (see the mirror image relationships over millennial scales in Fig. 4). This interpretation implies that both EM1 and EM2 have the same origin.

The grain size distribution of EM3 has a modal peak at $18.9 \mu \mathrm{m}$ (Fig. 3b). This population belongs to "subgroup 1.c.l" in Vandenberghe (2013). This population is also widespread in loess from the CLP and NE-TP (Prins and Vriend, 2007; Prins et al., 2007), as well as the Danube Basin loess of Europe (Bokhorst et al., 2011; Varga, 2011). It is also particularly common in loess of interglacial soil (Vriend, 2007). As of yet, there is no consensus regarding the transport processes responsible for this grain size population. On the one hand, researchers have suggested that grains of this size can be lifted by strong vertical air movement and subsequently incorporated into the high-level westerly air streams (Pye, 1995; Pye and Zhou, 1989). This process would link EM3 with long-term suspension transport driven by high-level westerlies (Nottebaum et al., 2014; Prins et al., 2007; Vandenberghe, 2013; Vriend et al., 2011). Conversely, Zhang et al. (1999) argued that $<20 \mu \mathrm{m}$ particle fractions derive from "non-dust storm processes" associated with northwesterly surface winds. We argue for the latter on the basis that the EM3 modal grain size from the CLP and NETP is coarser (Vriend et al., 2011) than EM3 at NLK in the Ili Valley, which is located further west. If EM3 was transported by high-level westerlies, then one would expect either no significant change (Rea and Hovan, 1995; Rea et al., 1985), or a decrease in grain size from west to east concomitant with wind direction. Furthermore, with mathematical fitting, Sun et al. (2004) related a fine component $(2-8 \mu \mathrm{m})$ to high-altitude westerlies. This fine component is comparable to "subgroup 1.c.2" of Vandenberghe (2013) but is not consistent with our modal size of EM3. Observations of modern 


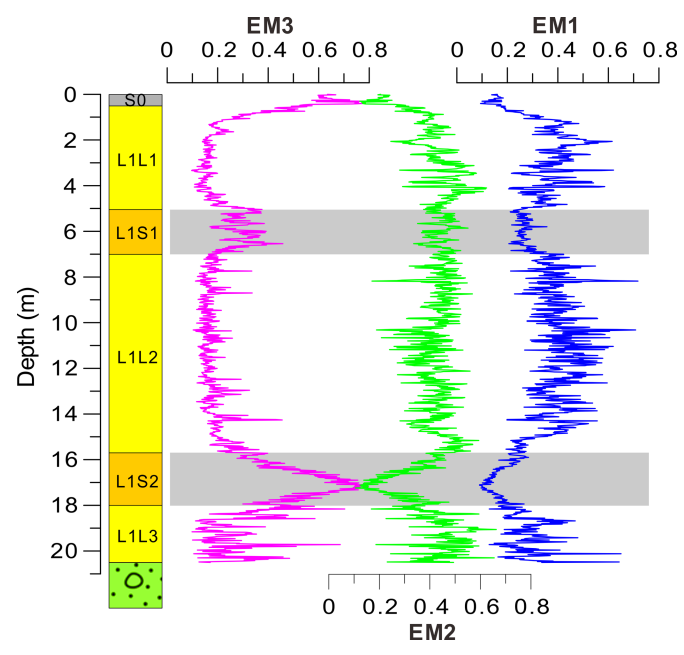

Figure 4. Proportional contributions of the three end-members in the NLK section.

eolian processes at the southern margins of the Tarim Basin indicate that fine grain sizes similar to EM3 $(8-15 \mu \mathrm{m})$ are deposited by settling during low-velocity wind conditions (Lin et al., 2016). Particle-size distributions of background dust from the northern slopes of the Tianshan Mountains also typically yield a modal peak of approximately $10 \mu \mathrm{m}$ (Schettler et al., 2014). We therefore infer the EM3 modal peak to derive from low altitude, non-dust storm processes.

Fine particles can also be incorporated into silt- or sandsized aggregates which can be transported by a range of wind velocities, including dust storms (Derbyshire et al., 1998; Mason et al., 2003; Pye, 1995; Qiang et al., 2010). For example, Ujvari et al. (2016) argued that $\sim 1-20 \mu \mathrm{m}$ fractions are affected by aggregation, as shown by comparison between minimally and fully dispersed grain size distribution measurements of loess samples from southern Hungary. Under higher wind velocity conditions, aggregates should co-vary with the coarser EM1 particles transported by surface winds during dust storms. However, since this model is unlikely to hold for EM3 particles (Fig. 4), the aggregate model is unlikely to be responsible for the presence of EM3 grain sizes at NLK.

Post-depositional processes may also influence grain size distribution. In large part this occurs due to chemical weathering which produces very fine silt and clay minerals (Hao et al., 2008; Wang et al., 2006; Xiao et al., 1995). Quartz grains are more resistant to weathering and remain largely unaltered during post-depositional processes. Consequently, quartz mineral grain size may be used as a more reliable proxy indicator of winter monsoon strength than other components (Sun et al., 2006; Xiao et al., 1995). Figure 6a shows the grain size distribution curves of quartz grains isolated from primary loess (yellow) and paleosol (red) samples. The quartz modal grain size is finer in the paleosol than in the primary loess unit. From this we can deduce that wind strength

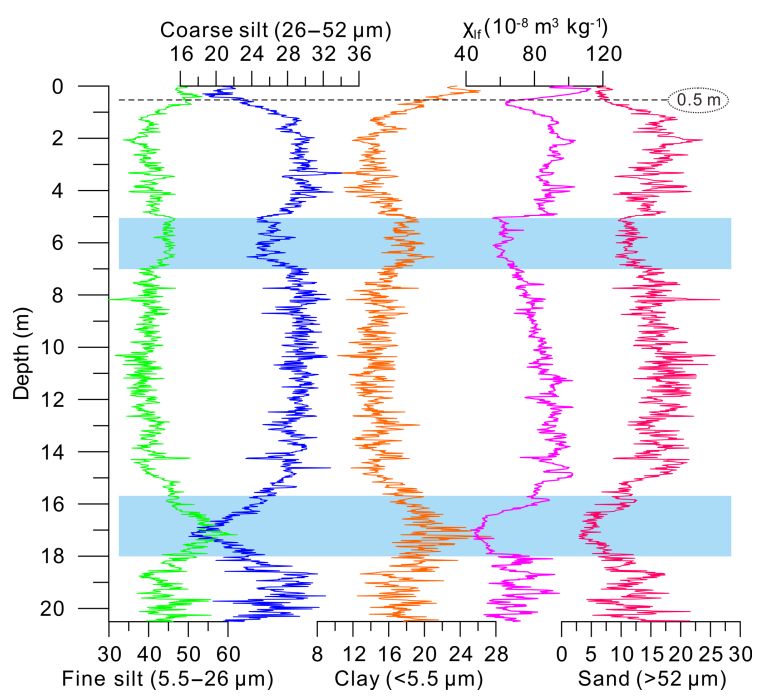

Figure 5. Comparison of different grain size fractions of NLK loess with $\chi_{\mathrm{lf}}$ (limits of grain size classes after Konert and Vandenberghe, 1997).

was weaker during pedogenesis and stronger during periods of primary loess deposition. The grain size distributions of bulk samples display similar characteristics with those of quartz samples mentioned above (Fig. 6b), since soil unit modal peaks (red and orange) are finer than those in the primary loess (blue and green). Therefore, we argue that wind strength, rather than the post-depositional pedogenesis, has the greatest influence on grain size distribution at NLK, and that EM3 was not produced by chemical weathering.

The relative proportions of the end-members down profile can yield information about temporal variability in wind dynamics. The fairly consistent proportions of EM3 within the loess units indicate it to represent continuous background dust through time (Vandenberghe, 2013). Proportions of EM1 and EM2 decrease noticeably within paleosol units relative to EM3 (Fig. 4). This indicates that variations in proportions of EM3 are mainly driven by variability in EM1 and EM2 (Vriend et al., 2011), and that consistent background sedimentation of EM3 continued during weak pedogenesis (Fig. 6c). This characteristic is comparable with observations from the CLP (Zhang et al., 1999).

In addition, small peaks at ca. $0.8 \mu \mathrm{m}$ are also observed in the grain size distribution curves of all three end-members. The generation of these fine grain peaks may be due to postdepositional pedogenesis, especially for particles $<2 \mu \mathrm{m}$ (Bronger and Heinkele, 1990). However, since the dominant modal peaks are much coarser, weaker post-depositional weathering as suggested by MS is unlikely to have had a significant influence on the populations of EM1, EM2, or EM3 at NLK. Other potential sources include transportation as aggregates or by the finest grains adhering to coarser particles during transport. Regardless of cause, these particles are unlikely to yield meaningful information about wind regime 

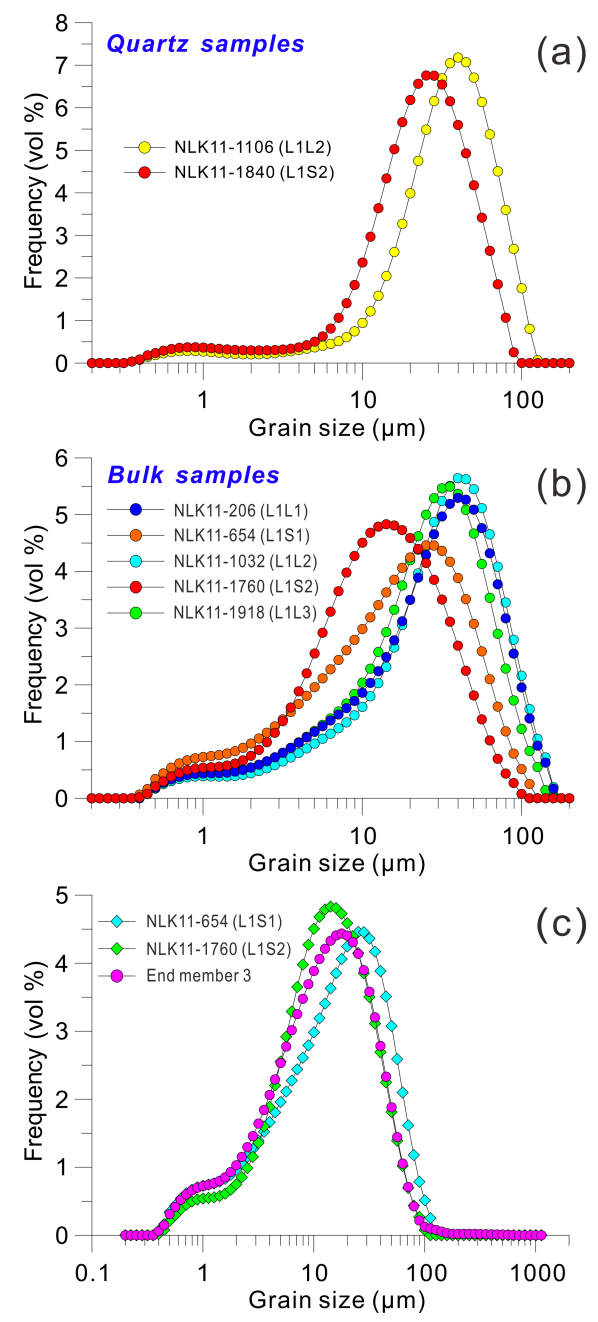

Figure 6. Comparisons of grain size distribution. (a) Between purified quartz subsamples of paleosol and primary loess. (b) Between bulk samples of paleosols and primary loess. (c) Between EM3 and samples from weak paleosol units.

variability or links to climate systems since they do not yield a clear independent end-member peak.

\subsection{Eolian dust dynamics in eastern Central Asia: links to atmospheric systems}

Variations in grain size through time at NLK were largely driven by changes in wind strength, without substantial influence of post-depositional pedogenesis. At NLK, grain size is therefore an indicator of loess response to climatic systems.

The three end-members are interpreted to represent different depositional processes which operated throughout the accumulation of the deposit. The finer EM3 is interpreted to represent constant background dust, which continued to accumulate throughout periods of relative stability and pedogenesis. The coarser populations, EM1 and EM2, were transported by low-level winds during major dust storms. EM1 is most likely the most sensitive recorder of wind intensity, since EM2 is less sensitive to wind speeds than EM1 by observation of variations in EM2 proportions throughout L1S1 and L1L2 (Fig. 4).

From published OSL data (Song et al., 2015), we used linear regression (Stevens et al., 2016) to construct age-depth relationships over intervals of visually similar sedimentation rate (Fig. S4 and Table S1 in the Supplement). We assessed the degree of correlation between wind strength variability in the Ili Valley (NLK), as represented by the proportions of EM1, with the stable oxygen isotope record from the Greenland ice cores representing North Atlantic paleoclimate (Rasmussen et al., 2014), the mean grain size (MGS) record of the Jingyuan loess section from the CLP (Sun et al., 2010), uranium (U) ratio (15.6-63.4 $\mu \mathrm{m} / 5.61-15.6 \mu \mathrm{m})$ of the Remizovka loess section in SE Kazakhstan (Machalett et al., 2008), and glacial advances in the Tian Shan (Koppes et al., 2008; Owen and Dortch, 2014) (Fig. 7).

EM1 occurs in higher proportions during mid-marine isotope stage (MIS) 3, with a higher rate of sedimentary accumulation (Fig. 7). Glaciers in the region expanded during early and late MIS3 (Owen and Dortch, 2014). The apparent chronological link between increased primary loess accumulation and glacial expansion in the region contrasts with trends elsewhere indicating increased dust accumulation during dry and windy glacial conditions, and pedogenesis under comparatively wetter interglacial conditions (Ding et al., 2002; Dodonov and Baiguzina, 1995; Stevens et al., 2013; Sun et al., 2010). Our observations suggest a seesaw relationship between increased loess accumulation and glacial expansion during MIS3 (Fig. 7), a model supported by Youn et al. (2014). Moisture availability appears to be the dominant factor controlling glacier growth in Central Asia, especially for glaciers in the Tian Shan (Koppes et al., 2008; Zech, 2012). Therefore, we infer that moisture had an important impact on the accumulation of dust in the study area during MIS3 in particular.

Central Asia is variably influenced by the Asian monsoon from the south (Cheng et al., 2012; Dettman et al., 2001), the mid-latitude westerlies (Vandenberghe et al., 2006), the Siberian High pressure system from the northeast (Youn et al., 2014), and the polar front from the north (Machalett et al., 2008). The Asian high mountains largely inhibit the intrusion of Asian (Indian and East Asian) monsoons to the region, since the Ili Valley is sheltered to the northeast, east, and south. Studies of the oxygen isotopic composition of precipitation in the Tian Shan Mountains region support this geographic situation by indicating a stronger connection with westerly circulation than with the Asian summer monsoon (Chen et al., 2016; Liu et al., 2015).

Modern satellite data indicates that dust storm development in the Ili river valley is closely linked with southwardmoving high-latitude air masses. The large, cold Siberian High pressure system is at the north-northeast of our study area, centering between 40 and $65^{\circ} \mathrm{N}$ and between 80 and 


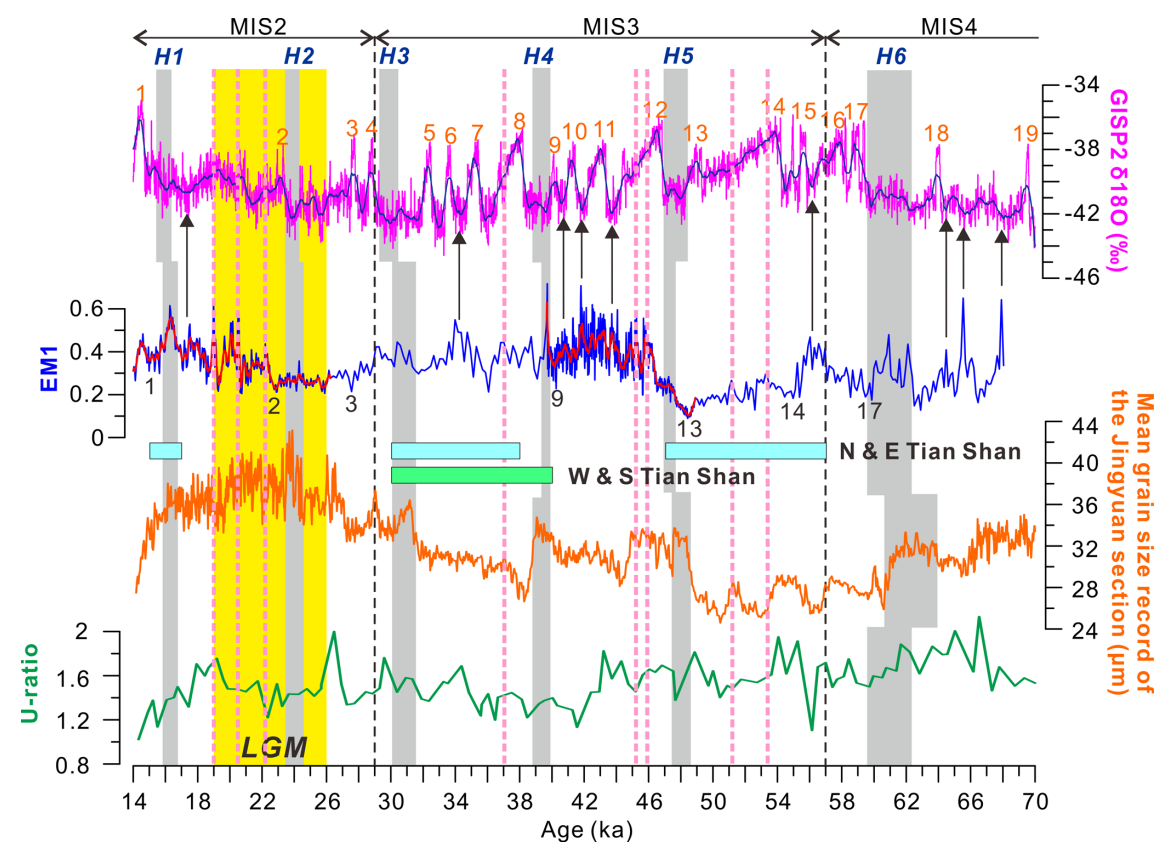

Figure 7. Comparison between EM1 grain size variability and the timing of glacial advances in the Tian Shan (Koppes et al., 2008; Owen and Dortch, 2014); stable oxygen isotope variations from the Greenland ice cores (Rasmussen et al., 2014); mean grain size (MGS) record of the Jingyuan loess section from the CLP (Sun et al., 2010) and; U-ratio (15.6-63.4 $\mu \mathrm{m}$ / 5.61-15.6 $\mu \mathrm{m}$ ) of the SE Kazakhstan loess (Machalett et al., 2008). A five-point running average was performed for the intervals with higher sedimentary rate on EM1 curve (red line).

$120^{\circ}$ E (cf. Fig. 3 in Huang et al., 2011). The Siberian anticyclone dominates winter and spring climate over Eurasia (Gong and Ho, 2002; Obreht et al., 2017; Panagiotopoulos et al., 2005; Sahsamanoglou et al., 1991). Although the influence of the Siberian High has been shown to decrease westward from the CLP (Vandenberghe et al., 2006), wind strength and frequency over the Aral Sea in western central Asia during the Holocene was nevertheless associated with the intensity of the Siberian High pressure system (Feng et al., 2011; Sorrel et al., 2007). Obreht et al. (2017) even hypothesized increased influence of the Siberian High during MIS 3 over the Lower Danube Basin in SE Europe, although this has yet to be substantiated. Moreover, the Siberian High was considered to be one of the most important influences on dust deposition based on the results of long-term monitoring over Central Asia between 2003 and 2010 (Groll et al., 2013).

Increases in modal grain size from the CLP are also linked to a strengthened East Asian winter monsoon due to intensification of the Siberian High (Ding et al., 1995; Hao et al., 2012). Therefore, the grain size record from the Chinese loess is a likely indicator of Siberian High intensity. We use the Jingyuan loess section as a point of comparison in our study because it is a high-resolution record located in the northwestern CLP that has a high sedimentation rate with the likelihood of preserving millennial-scale oscillations. We compared secular trends between the EM1 proportions and MGS data from Jingyuan over the last glacial period (Sun et al., 2010). Similarities can be observed (Fig. 7); coarser grain sizes and higher sedimentation rates are observed during mid-MIS3 (Sun et al., 2010), with the opposite occurring in early and late MIS3. This supports a common Eurasian atmospheric forcing pattern, the Siberian High, driving the climate evolution of the Ili Basin and CLP during that time period.

By comparison, the Last Glacial Maximum (LGM) experienced significantly different trends, despite increased sedimentation rates (Sun et al., 2010) (Fig. 7). EM1 proportions decrease particularly during the early LGM. We attribute this to a reduction in sediment supply, possibly linked to permafrost development in the Ili Basin and Kazakhstan steppe (Fig. 1) (Vandenberghe et al., 2014; Zhao et al., 2014). Reduced sediment supply therefore limits the degree to which grain size characteristics can reliably indicate wind strength during the LGM.

In presenting data from the Remizovka site in the more open western Ili Basin, Machalett et al. (2008) argued that the Arctic polar front, expanding southward in winter and retracting northward in summer, most likely increased the frequency and strength of cyclonic storms due to higher temperature and humidity gradients created between colder polar air and warmer tropical air (Harman, 1991). They hypothesized that this climate system was the predominant influence on dust transport and loess accumulation during cold phases along the Kyrgyz (southern) Tian Shan piedmont. While this may have been the case at Remizovka, it is unlikely to have 
affected NLK in the eastern Ili Basin since the eastern basin is much more sheltered due to the position of the mountain ranges (Fig. 1a).

To assess spatial variability in climatic influence across the Ili Basin, we compare the EM1 curve with the U-ratio (15.6$63.4 \mu \mathrm{m} / 5.61-15.6 \mu \mathrm{m})$ of the polar front-influenced Remizovka loess. We observe minimal similarities in the curves. These disparities suggest that two different atmospheric forcing patterns controlled loess accumulation from one end of the Ili Basin to the other. The differences appear to be particularly clear over MIS3 (Fig. 7), although problems with chronological integrity at the Remizovka site need to be resolved (Fitzsimmons et al., 2016) before we can argue this with confidence. In addition, U-ratios decrease during the LGM (Fig. 7), supporting our hypothesis that the development of permafrost limits the availability of source sediments for loess in this region.

We argue that the Siberian High pressure system exerts a significant influence on wind dynamics and loess deposition in the eastern Ili Basin. It is evident that the strongest winds at NLK mainly blow from the west (Table S2), although northerly high-latitude air masses with potential for short-term dust transport can enter the Ili Basin by deflection around the northern Tian Shan mountains (Fig. S5).

Enhanced evaporation, coupled with strengthened westerly winds, would bring more humidity and warmer conditions to ACA during the Holocene (Zhang et al., 2016). Karger et al. (2017) reconstructed the dynamics of the westerlies in the Ili Basin, proposing a rain belt which seasonally migrates towards the south and north in autumn and summer, respectively. A strengthened Siberian High would push the mid-latitude westerlies pathways further to the south, resulting in comparably drier conditions in northeastern Central Asia (e.g., Tian Shan) and conversely, wetter conditions in southwestern Central Asia (Pamir) (Lei et al., 2014; Wolff et al., 2017). The intensity and geographical position of the Siberian High would most likely impact precipitation and atmospheric circulation patterns (meridional or zonal) in the mid-latitudes of Central Asia (Panagiotopoulos et al., 2005). It is therefore most likely that the mid-latitude westerlies controlled broad-scale patterns of moisture variation across ACA broadly (Cai et al., 2017; Huang et al., 2015; Li et al., 2011), whereas the eastern Ili Basin experienced the combined influence of the Siberian High and mid-latitude westerlies system.

Comparison of EM1 proportions with variability in Greenland Ice Sheet Project (GISP) $\delta^{18} \mathrm{O}$ suggests that our grain size proxy data may correlate with abrupt events, such as North Atlantic Heinrich events H1 to H6 (Fig. 7), although this correlation cannot yet be better constrained due to limitations in the chronological dataset. Some of the peaks in EM1 curve correspond to troughs in GISP $\delta^{18} \mathrm{O}$ curve (black arrows in Fig. 7) outside Heinrich events, yet many do not (pink dashed lines in Fig. 7). Potential causes of this discrep- ancy may lie in variability in local source availability and wind dynamics at certain points in time.

Comparisons between the eastern Ili Basin and Chinese Loess Plateau loess further elucidates complexity in the climatic signal preserved in the ACA. The NLK EM1 proportions in the Ili Basin yield lower variability than the Jingyuan MGS on the CLP, particularly during H2 and H5 (Fig. 7). We attribute these differences to local source sediment availability at NLK. EM1 supply to NLK was reduced during H2 due to the development of permafrost, and during H5 due to increased vegetation cover associated with more humid conditions inhibiting coarse grain entrainment (Fig. 7). By contrast, the relatively more arid mid-MIS3, indicated by glacial retreat in the Tian Shan, may have decreased vegetation cover and increased entrainment potential and transport to NLK (Fig. 7); these conditions and this trend was also observed in the NE-TP (Vriend et al., 2011). The differences may be because the loess records in our study area represent a response not only to hemispheric climate systems, but also to local influences such as local atmospheric circulation and topography. Since the sedimentary response to changing climate conditions in more arid Central Asia is different to that of the more temperate European loess (Rousseau et al., 2007), we must be careful about investigating the mechanisms of Eolian dynamics and loess accumulation in our paleoclimatic interpretations of ACA loess archives.

Many studies have speculated that millennial-scale oscillations represent a teleconnection between the North Atlantic and East Asia (e.g., Porter and An, 1995; Yang and Ding, 2014), although the dynamics involved are poorly understood. Porter and An (1995) and Sun et al. (2012) suggested, based on CLP loess physical characteristics, that a strong influence from the westerlies resulted in transport of the North Atlantic signal to East Asia. Conversely, Yang and Ding (2014) proposed that millennial-scale North Atlantic climate signals might have been transmitted to the Siberian High via the Barents and Kara Sea ice sheets, and were propagated eastwards to the CLP via the winter monsoon system. In the western CLP (Chen et al., 1997), for example, evidence of millennial-scale (likely Heinrich) events are preserved within the loess stratigraphy during phases of strong winter monsoon in China; however, not all of the strong winter monsoon events in China correlate with Heinrich events in the North Atlantic, so challenging the Yang and Ding (2014) hypothesis.

Stronger datasets from Central Asia may provide the missing link for understanding climate teleconnections between the two extreme ends of the Eurasian continent. In doing so, however, the scale of the Central Asian region must be taken into account. At Darai Kalon in Tajikistan, $1200 \mathrm{~km}$ southwest of NLK, the mid-latitude westerlies clearly have a strong influence on dust transport and loess accumulation; Atlantic signals are clearly identified in grain size variations, especially during full glacial phases (Vandenberghe et al., 2006). Since the CLP lies at a similar latitude to Darai 
Kalon, mid-latitude westerlies have the potential to transport North Atlantic climate signals to East Asia. By contrast, since NLK is located substantially further north than Darai Kalon and the CLP, the Siberian High exerts a greater influence on wind dynamics and therefore loess deposits. A strengthened Siberian High would affect a southward shift of the mid-latitude westerlies pathways; under such conditions, NLK would not be as strongly influenced by the midlatitude westerlies. This argument is further supposed by the lack of correlation between NLK EM1 proportions and GISP $\delta^{18} \mathrm{O}$ values during relatively mild interstadial periods (Dansgaard-Oeschger cycles) when the mid-latitude westerlies shift northwards (Fig. 7). Therefore, NLK provides a strategic location for investigating the potential role of the Siberian High in transmitting North Atlantic climate signals to East Asia. The preservation of North Atlantic several millennial-scale Heinrich events at NLK supports the argument for the influence of the Siberian High as proposed by Yang and Ding (2014).

\section{Conclusion}

Our data from NLK in the eastern Ili Basin provide a paleoenvironmental record over the last ca. 70 kyr. The magnetic properties of the loess do not correlate with pedogenesis in this section; rather, wind strength is mainly responsible for variations in physical characteristics over the last glacial period.

Three grain size end-members were identified at NLK: EM1 (mode size at $47.5 \mu \mathrm{m})$, EM2 $(33.6 \mu \mathrm{m})$ and EM3 $(18.9 \mu \mathrm{m})$. They each indicate different kinds of depositional processes which operated throughout the accumulation of the loess. EM1 and EM2 represent grain size fractions transported from proximal sources in short-term, near-surface suspension during dust outbreaks, and may have the same origin. While wind strength controls their relative proportions, EM1 is the most sensitive recorder of wind strength. EM3 represents continuous background dust under non-dust storm conditions.

The Siberian High pressure system predominates in the eastern Ili Basin during cold phases, which leads to dust transport and increased loess accumulation at NLK. Many rapid cooling events, including six Heinrich events, were imprinted in the NLK loess. Our grain size data support the argument that the Siberian High plays a significant role in transporting North Atlantic climatic signals to East Asia via ice sheets in the high northern latitudes.

Data availability. The raw grain size and magnetic susceptibility data for the Nilka loess section are publicly accessible on the GitHub repository: https://github.com/YueLi-ieecas/ Central-Asia-loess.git (Li et al., 2018).
Supplement. The supplement related to this article is available online at: https://doi.org/10.5194/cp-14-271-2018-supplement.

Competing interests. The authors declare that they have no conflict of interest.

Acknowledgements. The project is supported by the National Key Research and Development Program of China (no. 2016YFA0601902), Natural Science Foundation of China (no. 41572162), International Partnership Program (No. 132B61KYS20160002) and Special Exchange Program for Russia, Ukraine, and Belarus from the Chinese Academy of Science. The authors thank Chuanxiang Li and Junchao Dong from the Institute of Earth Environment, Chinese Academy of Sciences, for their assistance in the experiments and sampling, and Jia Li from Xiamen University for her assistance in mathematical treatment.

Edited by: Liping Zhou

Reviewed by: Jef Vandenberghe and one anonymous referee

\section{References}

Antoine, P., Rousseau, D.-D., Moine, O., Kunesch, S., Hatté, C., Lang, A., Tissoux, H., and Zöller, L.: Rapid and cyclic aeolian deposition during the Last Glacial in European loess: a highresolution record from Nussloch, Germany, Quaternay Sci. Rev., 28, 2955-2973, 2009.

Beget, J. E. and Hawkins, D. B.: Influence of Orbital Parameters on Pleistocene Loess Deposition in Central Alaska, Nature, 337, 151-153, 1989.

Blott, S. J. and Pye, K.: GRADISTAT: a grain size distribution and statistics package for the analysis of unconsolidated sediments, Earth Surf. Proc. Land., 26, 1237-1248, https://doi.org/10.1002/esp.261, 2001.

Bokhorst, M. P., Vandenberghe, J., Sumegi, P., Lanczont, M., Gerasimenko, N. P., Matviishina, Z. N., Markovic, S. B., and Frechen, M.: Atmospheric circulation patterns in central and eastern Europe during the Weichselian Pleniglacial inferred from loess grain-size records, Quatern. Int., 234, 62-74, 2011.

Bond, G., Heinrich, H., Broecker, W., Labeyrie, L., Mcmanus, J., Andrews, J., Huon, S., Jantschik, R., Clasen, S., Simet, C., Tedesco, K., Klas, M., Bonani, G., and Ivy, S.: Evidence for massive discharges of icebergs into the North Atlantic Ocean during the last glacial period, Nature, 360, 245-249, 1992.

Bronger, A. and Heinkele, T.: Mineralogical and clay mineralogical aspects of loess research, Quatern. Int., 7, 37-51, 1990.

Buggle, B., Hambach, U., Glaser, B., Gerasimenko, N., Markovic, S., Glaser, I., and Zöller, L.: Stratigraphy, and spatial and temporal paleocliamtic trends in Southeastern/Eastern European loesspaleosol sequences, Quatern. Int., 196, 86-106, 2009.

Buggle, B., Hambach, U., Muller, K., Zoller, L., Markovic, S. B., and Glaser, B.: Iron mineralogical proxies and Quaternary climate change in SE-European loess-paleosol sequences, Catena, $117,4-22,2014$. 
Cai, Y. J., Chiang, J. C. H., Breitenbach, S. F. M., Tan, L. C., Cheng, H., Edwards, R. L., and An, Z. S.: Holocene moisture changes in western China, Central Asia, inferred from stalagmites, Quaternary Sci. Rev., 158, 15-28, 2017.

Chen, F., Bloemendal, J., Wang, J., Li, J., and Oldfield, F.: Highresolution multi-proxy climate records from Chinese loess: evidence for rapid climatic changes over the last $75 \mathrm{kyr}$, Palaeogeogr. Palaeocl., 130, 323-335, 1997.

Chen, F. H., Jia, J., Chen, J. H., Li, G. Q., Zhang, X. J., Xie, H. C., Xia, D. S., Huang, W., and An, C. B.: A persistent Holocene wetting trend in arid central Asia, with wettest conditions in the late Holocene, revealed by multi-proxy analyses of loess-paleosol sequences in Xinjiang, China, Quaternary Sci. Rev., 146, 134-146, 2016.

Cheng, H., Zhang, P. Z., Spotl, C., Edwards, R. L., Cai, Y. J., Zhang, D. Z., Sang, W. C., Tan, M., and An, Z. S.: The climatic cyclicity in semiarid-arid central Asia over the past 500,000 years, Geophys. Res. Lett., 39, L01705, https://doi.org/10.1029/2011GL050202, 2012.

Dansgaard, W., Johnsen, S. J., Clausen, H. B., Hvidberg, C. S., and Steffensen, J. P.: Evidence for general instability of past climate from a 250-kyr ice-core record, Nature, 364, 218-220, 1993.

Derbyshire, E., Meng, X. M., and Kemp, R. A.: Provenance, transport and characteristics of modern aeolian dust in western Gansu Province, China, and interpretation of the Quaternary loess record, J. Arid Environ., 39, 497-516, 1998.

Dettman, D. L., Kohn, M. J., Quade, J., Ryerson, F. J., Ojha, T. P., and Hamidullah, S.: Seasonal stable isotope evidence for a strong Asian monsoon throughout the past 10.7 m.y., Geology, 29, 3134, 2001.

Ding, Z., Liu, T., Rutter, N. W., Yu, Z., Guo, Z., and Zhu, R.: Icevolume forcing of East Asian winter monsoon variations in the past 800,000 years, Quaternary Res., 44, 149-159, 1995.

Ding, Z. L., Sun, J. M., Rutter, N. W., Rokosh, D., and Liu, T. S.: Changes in sand content of loess deposits along a north-south transect of the Chinese Loess Plateau and the implications for desert variations, Quaternary Res., 52, 56-62, 1999.

Ding, Z. L., Ranov, V., Yang, S. L., Finaev, A., Han, J. M., and Wang, G. A.: The loess record in southern Tajikistan and correlation with Chinese loess, Earth Planet. Sc. Lett., 200, 387-400, 2002.

DiPietro, L. M., Driese, S. G., Nelson, T. W., and Harvill, J. L.: Variations in late Quaternary wind intensity from grain-size partitioning of loess deposits in the Nenana River Valley, Alaska, Quaternary Res., 87, 258-274, 2017.

Dodonov, A. E. and Baiguzina, L. L.: Loess stratigraphy of Central Asia: Palaeoclimatic and palaeoenvironmental aspects, Quaternary Sci. Rev., 14, 707-720, 1995.

Dodonov, A. E., Sadchikova, T. A., Sedov, S. N., Simakova, A. N., and Zhou, L. P.: Multidisciplinary approach for paleoenvironmental reconstruction in loess-paleosol studies of the Darai Kalon section, Southern Tajikistan, Quatern. Int., 152, 48-58, 2006.

Fang, X. M., Shi, Z. T., Yang, S. L., Yan, M. D., Li, J. J., and Jiang, P. A.: Loess in the Tian Shan and its implications for the development of the Gurbantunggut Desert and drying of northern Xinjiang, Chinese Sci. Bull., 47, 1381-1387, 2002.

Feng, Z. D., Ran, M., Yang, Q. L., Zhai, X. W., Wang, W., Zhang, X. S., and Huang, C. Q.: Stratigraphies and chronologies of late
Quaternary loess-paleosol sequences in the core area of the central Asian arid zone, Quatern. Int., 240, 156-166, 2011.

Fitzsimmons, K. E., Sprafke, T., Zielhofer, C., Günter, C., Deom, J. M., Sala, R., and Iovita, R.: Loess accumulation in the Tian Shan piedmont: Implications for palaeoenvironmental change in arid Central Asia, Quatern. Int., https://doi.org/10.1016/j.quaint.2016.07.041, online first, 2016.

Folk, R. L. and Ward, W. C.: Brazos River bar: a study in the significance of grain size parameters, J. Sediment. Res., 27, 3-26, 1957.

Gong, D. Y. and Ho, C. H.: The Siberian High and climate change over middle to high latitude Asia, Theor. Appl. Climatol., 72, 19, 2002.

Grimley, D. A. and Arruda, N. K.: Observations of magnetite dissolution in poorly drained soils, Soil Sci., 172, 968-982, 2007.

Groll, M., Opp, C., and Aslanov, I.: Spatial and temporal distribution of the dust deposition in Central Asia - results from a long term monitoring program, Aeolian Res., 9, 49-62, 2013.

Hao, Q., Wang, L., Oldfield, F., Peng, S., Qin, L., Song, Y., Xu, B., Qiao, Y., Bloemendal, J., and Guo, Z.: Delayed build-up of Arctic ice sheets during 400,000-year minima in insolation variability, Nature, 490, 393-396, 2012.

Hao, Q. Z., Oldfield, F., Bloemendal, J., and Guo, Z. T.: Particle size separation and evidence for pedogenesis in samples from the Chinese Loess Plateau spanning the past 22 m.y., Geology, 36, 727-730, 2008.

Harman, J. R.: Synoptic Climatology of the Westerlies: Process and Patterns, Association of American Geographers, Washington, DC, 1991.

Heller, F. and Evans, M. E.: Loess magnetism, Rev. Geophys., 33, 211-240, 1995.

Heller, F. and Liu, T. S.: Magnetism of Chinese Loess Deposits, Geophys. J. Roy. Astr. S., 77, 125-141, 1984.

Heller, F., Shen, C. D., Beer, J., Liu, X. M., Liu, T. S., Bronger, A., Suter, M., and Bonani, G.: Quantitative Estimates of Pedogenic Ferromagnetic Mineral Formation in Chinese Loess and Paleoclimatic Implications, Earth Planet. Sc. Lett., 114, 385-390, 1993.

Huang, W., Chen, J. H., Zhang, X. J., Feng, S., and Chen, F. H.: Definition of the core zone of the "westerlies-dominated climatic regime", and its controlling factors during the instrumental period, Sci. China Earth Sci., 58, 676-684, 2015.

Huang, X. T., Oberhansli, H., von Suchodoletz, H., and Sorrel, P.: Dust deposition in the Aral Sea: implications for changes in atmospheric circulation in central Asia during the past 2000 years, Quaternary Sci. Rev., 30, 3661-3674, 2011.

Jacobs, P. M., Mason, J. A., and Hanson, P. R.: Mississippi Valley regional source of loess on the southern Green Bay Lobe land surface, Wisconsin, Quaternary Res., 75, 574-583, 2011.

Jia, J., Xia, D. S., Wei, H. T., Wang, B., and Liu, X. B.: A magnetic investigation of a loess/paleosol sequences record in Ili area, Front. Earth. Sci-Prc., 4, 259-268, 2010.

Jia, J., Xia, D. S., Wang, B., Wei, H. T., and Liu, X. B.: Magnetic investigation of Late Quaternary loess deposition, Ili area, China, Quatern. Int., 250, 84-92, 2012.

Karger, D. N., Conrad, O., Böhner, J., Kawohl, T., Kreft, H., Soria-Auza, R. W., Zimmermann, N., Linder, H. P., and Kessler, M.: Climatologies at high resolution for 
the Earth land surface areas, Scientific Data, 4, 170122, https://doi.org/10.1038/sdata.2017.122, 2017.

Konert, M. and Vandenberghe, J.: Comparison of laser grain size analysis with pipette and sieve analysis: A solution for the underestimation of the clay fraction, Sedimentology, 44, 523-535, 1997.

Koppes, M., Gillespie, A. R., Burke, R. M., Thompson, S. C., and Stone, J.: Late Quaternary glaciation in the Kyrgyz Tien Shan, Quaternary Sci. Rev., 27, 846-866, 2008.

Lei, Y. B., Tian, L. D., Bird, B. W., Hou, J. Z., Ding, L., Oimahmadov, I., and Gadoev, M.: A 2540-year record of moisture variations derived from lacustrine sediment (Sasikul Lake) on the Pamir Plateau, Holocene, 24, 761-770, 2014.

Li, G. Q., Rao, Z. G., Duan, Y. W., Xia, D. S., Wang, L. B., Madsen, D. B., Jia, J., Wei, H. T., Qiang, M. R., Chen, J. H., and Chen, F. H.: Paleoenvironmental changes recorded in a luminescence dated loess/paleosol sequence from the Tianshan Mountains, arid central Asia, since the Penultimate Glaciation, Earth Planet. Sc. Lett., 448, 1-12, 2016.

Li, J.: Climate in Xinjiang, China Meteorological Press, Beijing, 1991.

Li, X., Zhao, K., Dodson, J., and Zhou, X.: Moisture dynamics in central Asia for the last $15 \mathrm{kyr}$ : new evidence from Yili Valley, Xinjiang, NW China, Quaternary Sci. Rev., 30, 3457-3466, 2011.

Li, Y., Song, Y. G., Yan, L. B., Chen, T., and An, Z. S.: Timing and Spatial Distribution of Loess in Xinjiang, NW China, PloS ONE, 10, e0125492, https://doi.org/10.1371/journal.pone.0125492, 2015.

Li, Y., Song, Y., Lai, Z., Han, L., and An, Z.: Rapid and cyclic dust accumulation during MIS 2 in Central Asia inferred from loess OSL dating and grain-size analysis, Sci. Rep., 6, 32365, https://doi.org/10.1038/srep32365, $2016 \mathrm{a}$.

Li, Y., Song, Y. G., Chen, X. L., Li, J. C., Mamadjanov, Y., and Aminov, J.: Geochemical composition of Tajikistan loess and its provenance implications, Palaeogeogr. Palaeocl., 446, 186-194, $2016 b$.

Li, Y., Song, Y., Zeng, M., Lin, W., Orozbaev, R., Cheng, L., Chen, X., and Halmurat, T.: Evaluating the paleoclimatic significance of clay mineral records from a late Pleistocene loesspaleosol section of the Ili Basin, Central Asia, Quaternary Res., https://doi.org/10.1017/qua.2017.58, online first, 2017.

Li, Y., Song, Y. G., Fitzsimmons, K. E., Chang, H., Orozbaev, R., and Li, X.: Aeolian dust records of the past in the Central Asia, available at: https://github.com/YueLi-ieecas/ Central-Asia-loess, last access: 2 March 2018.

Lin, Y. C., Mu, G. J., Xu, L. S., and Zhao, X.: The origin of bimodal grain-size distribution for aeolian deposits, Aeolian Res., 20, 8088, 2016.

Liu, Q. S., Deng, C. L., Torrent, J., and Zhu, R. X.: Review of recent developments in mineral magnetism of the Chinese loess, Quaternary Sci. Rev., 26, 368-385, 2007.

Liu, Q. S., Roberts, A. P., Larrasoana, J. C., Banerjee, S. K., Guyodo, Y., Tauxe, L., and Oldfield, F.: Environmental Magnetism: Principles and Applications, Rev. Geophys., 50, RG4002, https://doi.org/10.1029/2012RG000393, 2012.

Liu, T. S.: Loess and the Environment, China Ocean Press, Beijing, 1985.
Liu, X., Liu, Z., Lü, B., Markoviæ, S., Chen, J., Guo, H., Ma, M., Zhao, G., and Feng, H.: The magnetic properties of Serbian loess and its environmental significance, Chinese Sci. Bull., 58, 353363, 2013.

Liu, X. K., Rao, Z. G., Zhang, X. J., Huang, W., Chen, J. H., and Chen, F. H.: Variations in the oxygen isotopic composition of precipitation in the Tianshan Mountains region and their significance for the Westerly circulation, J. Geogr. Sci., 25, 801-816, 2015.

Liu, X. M., Shaw, J., Liu, T. S., Heller, F., and Yuan, B. Y.: Magnetic Mineralogy of Chinese Loess and Its Significance, Geophys. J. Int., 108, 301-308, 1992.

Liu, X. M., Rolph, T., Bloemendal, J., Shaw, J., and Liu, T. S.: Remanence characteristics of different magnetic grain size categories at Xifeng, central Chinese Loess Plateau, Quaternary Res., 42, 162-165, 1994.

Liu, X. M., Hesse, P., Rolph, T., and Begét, J. E.: Properties of magnetic mineralogy of Alaskan loess: evidence for pedogenesis, Quatern. Int., 62, 93-102, 1999.

Lu, H. Y. and An, Z. S.: Paleoclimatic significance of grain size of loess-palaeosol deposit in Chinese Loess Plateau, Sci. China Ser. D, 41, 626-631, 1998.

Lu, H. Y. and An, Z. S.: Pretreatment methods in loess-palaeosol granulometry, Chinese Sci. Bull., 42, 237-240, 1997.

Machalett, B., Frechen, M., Hambach, U., Oches, E. A., Zoller, L., and Markovic, S. B.: The loess sequence from Remisowka (northern boundary of the Tien Shan Mountains, Kazakhstan) Part I: Luminescence dating, Quatern. Int., 152, 192-201, 2006.

Machalett, B., Oches, E. A., Frechen, M., Zoller, L., Hambach, U., Mavlyanova, N. G., Markovic, S. B., and Endlicher, W.: Aeolian dust dynamics in central Asia during the Pleistocene: Driven by the long-term migration, seasonality, and permanency of the Asiatic polar front, Geochem. Geophy. Geosy., 9, Q08Q09, https://doi.org/10.1029/2007GC001938, 2008.

Maher, B. and Thompson, R.: Paleoclimatic significance of the mineral magnetic record of the Chinese loess and paleosols, Quaternary Res., 37, 155-170, 1992.

Maher, B. A.: Magnetic properties of modern soils and Quaternary loessic paleosols: paleoclimatic implications, Palaeogeogr Palaeocl., 137, 25-54, 1998.

Maher, B. A.: Palaeoclimatic records of the loess/palaeosol sequences of the Chinese Loess Plateau, Quaternary Sci. Rev., 154, 23-84, 2016.

Maher, B. A. and Taylor, R. M.: Formation of Ultrafine-Grained Magnetite in Soils, Nature, 336, 368-370, 1988.

Mason, J. A., Jacobs, P. M., Greene, R. S. B., and Nettleton, W. D.: Sedimentary aggregates in the Peoria Loess of Nebraska, USA, Catena, 53, 377-397, 2003.

Muhs, D. R.: The geologic records of dust in the Quaternary, Aeolian Res., 9, 3-48, 2013.

Muhs, D. R. and Bettis, E. A.: Quaternary loess-paleosol sequences as examples of climate-driven sedimentary extremes, Geol. Soc. Am. Spec. Pap., 370, 53-74, 2003.

Nawrocki, J., Wojcik, A., and Bogucki, A.: The magnetic susceptibility record in the Polish and western Ukrainian loess-palaeosol sequences conditioned by palaeoclimate, Boreas, 25, 161-169, 1996.

Nottebaum, V., Lehmkuhl, F., Stauch, G., Hartmann, K., Wunnemann, B., Schimpf, S., and Lu, H. Y.: Regional grain size vari- 
ations in aeolian sediments along the transition between Tibetan highlands and north-western Chinese deserts - the influence of geomorphological settings on aeolian transport pathways, Earth Surf. Proc. Land., 39, 1960-1978, 2014.

Nottebaum, V., Stauch, G., Hartmann, K., Zhang, J. R., and Lehmkuhl, F.: Unmixed loess grain size populations along the northern Qilian Shan (China): Relationships between geomorphologic, sedimentologic and climatic controls, Quatern. Int., 372, 151-166, 2015.

Obreht, I., Zeeden, C., Schulte, P., Hambach, U., Eckmeier, E., Timar-Gabor, A., and Lehmkuhl, F.: Aeolian dynamics at the Orlovat loess-paleosol sequence, northern Serbia, based on detailed textural and geochemical evidence, Aeolian Res., 18, 6981, 2015.

Obreht, I., Hambach, U., Veres, D., Zeeden, C., Bösken, J., Stevens, T., Markoviæ, S. B., Klasen, N., Brill, D., and Burow, C.: Shift of large-scale atmospheric systems over Europe during late MIS 3 and implications for Modern Human dispersal, Sci. Rep., 7, 5848, https://doi.org/10.1038/s41598-017-06285-x, 2017.

Owen, L. A. and Dortch, J. M.: Nature and timing of Quaternary glaciation in the Himalayan-Tibetan orogen, Quaternary Sci. Rev., 88, 14-54, 2014.

Panagiotopoulos, F., Shahgedanova, M., Hannachi, A., and Stephenson, D. B.: Observed trends and teleconnections of the Siberian high: A recently declining center of action, J. Climate, 18, 1411-1422, 2005.

Porter, S. C. and An, Z. S.: Correlation between climate events in the North-Atlantic and China during Last Glaciation, Nature, 375, 305-308, 1995.

Prins, M. A. and Vriend, M.: Glacial and interglacial eolian dust dispersal patterns across the Chinese Loess Plateau inferred from decomposed loess grain-size records, Geochem. Geophy. Geosy., 8, Q07Q05, https://doi.org/10.1029/2006GC001563, 2007.

Prins, M. A., Vriend, M., Nugteren, G., Vandenberghe, J., Lu, H. Y., Zheng, H. B., and Weltje, G. J.: Late Quaternary aeolian dust input variability on the Chinese Loess Plateau: inferences from unmixing of loess grain-size records, Quaternary Sci. Rev., 26, 230-242, 2007.

Prins, M. A., Zheng, H. B., Beets, K., Troelstra, S., Bacon, P., Kamerling, I., Wester, W., Konert, M., Huang, X. T., Ke, W., and Vandenberghe, J.: Dust supply from river floodplains: the case of the lower Huang He (Yellow River) recorded in a loess-palaeosol sequence from the Mangshan Plateau, J. Quaternary Sci., 24, 7584, 2009.

Pye, K.: Aeolian Dust and Dust Deposits, Academic Press, London, 1987.

Pye, K.: The nature, origin and accumulation of loess, Quaternary Sci. Rev., 14, 653-667, 1995.

Pye, K. and Zhou, L. P.: Late Pleistocene and Holocene Aeolian Dust Deposition in North China and the Northwest PacificOcean, Palaeogeogr. Palaeocl., 73, 11-23, 1989.

Qiang, M., Lang, L., and Wang, Z.: Do fine-grained components of loess indicate westerlies: Insights from observations of dust storm deposits at Lenghu (Qaidam Basin, China), J. Arid Environ., 74, 1232-1239, 2010.

Qin, X. G., Cai, B. G., and Liu, T. S.: Loess record of the aerodynamic environment in the east Asia monsoon area since 60,000 years before present, J. Geophys. Res.-Sol. Ea., 110, B01204, https://doi.org/10.1029/2004JB003131, 2005.
Rasmussen, S. O., Bigler, M., Blockley, S. P., Blunier, T., Buchardt, S. L., Clausen, H. B., Cvijanovic, I., Dahl-Jensen, D., Johnsen, S. J., Fischer, H., Gkinis, V., Guillevic, M., Hoek, W. Z., Lowe, J. J., Pedro, J. B., Popp, T., Seierstad, I. K., Steffensen, J. P., Svensson, A. M., Vallelonga, P., Vinther, B. M., Walker, M. J. C., Wheatley, J. J., and Winstrup, M.: A stratigraphic framework for abrupt climatic changes during the Last Glacial period based on three synchronized Greenland ice-core records: refining and extending the INTIMATE event stratigraphy, Quaternary Sci. Rev., 106, 14-28, 2014.

Rea, D. K. and Hovan, S. A.: Grain-Size Distribution and Depositional Processes of the Mineral Component of Abyssal Sediments - Lessons from the North Pacific, Paleoceanography, 10, 251-258, 1995.

Rea, D. K., Leinen, M., and Janecek, T. R.: Geologic Approach to the Long-Term History of Atmospheric Circulation, Science, 227, 721-725, 1985.

Rousseau, D. D., Sima, A., Antoine, P., Hatté, C., Lang, A., and Zöller, L.: Link between European and North Atlantic abrupt climate changes over the last glaciation, Geophys. Res. Lett., 34, L22713, https://doi.org/10.1029/2007GL031716, 2007.

Sahsamanoglou, H. S., Makrogiannis, T. J., and Kallimopoulos, P. P.: Some Aspects of the Basic Characteristics of the Siberian Anticyclone, Int. J. Climatol., 11, 827-839, 1991.

Schettler, G., Shabunin, A., Kemnitz, H., Knoeller, K., Imashev, S., Rybin, A., and Wetzel, H. U.: Seasonal and diurnal variations in dust characteristics on the northern slopes of the Tien Shan Grain-size, mineralogy, chemical signatures and isotope composition of attached nitrate, J. Asian Earth Sci., 88, 257-276, 2014.

Smalley, I. J., Mavlyanova, N. G., Rakhmatullaev, K. L., Shermatov, M. S., Machalett, B., Dhand, K. O., and Jefferson, I. F.: The formation of loess deposits in the Tashkent region and parts of Central Asia; and problems with irrigation, hydrocollapse and soil erosion, Quatern. Int., 152, 59-69, 2006.

Song, Y., Lai, Z., Li, Y., Chen, T., and Wang, Y.: Comparison between luminescence and radiocarbon dating of late Quaternary loess from the Ili Basin in Central Asia, Quat. Geochronol., 30, 405-410, 2015.

Song, Y., Zeng, M., Chen, X., Li, Y., Chang, H., An, Z., and Guo, X.: Abrupt climatic events recorded by the Ili loess during the last glaciation in Central Asia: Evidence from grain-size and minerals, J. Asian Earth Sci., 155, 58-67, https://doi.org/10.1016/j.jseaes.2017.10.040, 2018a.

Song, Y., Luo, D., Du, J., Kang, S., Cheng, P., Fu, C., and Guo, X.: Radiometric dating of late Quaternary loess in the northern piedmont of South Tianshan Mountains: Implications for reliable dating, Geol. J., https://doi.org/10.1002/gj.3129, online first, 2018b.

Song, Y. G., Shi, Z. T., Fang, X. M., Nie, J. S., Naoto, I., Qiang, X. K., and Wang, X. L.: Loess magnetic properties in the Ili Basin and their correlation with the Chinese Loess Plateau, Sci. China Earth Sci., 53, 419-431, 2010.

Song, Y. G., Li, C. X., Zhao, J. D., Cheng, P., and Zeng, M. X.: A combined luminescence and radiocarbon dating study of the Ili loess, Central Asia, Quat. Geochronol., 10, 2-7, 2012.

Song, Y. G., Chen, X. L., Qian, L. B., Li, C. X., Li, Y., Li, X. X., Chang, H., and An, Z. S.: Distribution and composition of loess sediments in the Ili Basin, Central Asia, Quatern. Int., 334, 6173,2014 . 
Song, Y. G., Li, Y., Li, Y., An, Z., Cheng, L., Sun, H., and Rustam, O.: North Atlantic Abrupt Climate Signals during the Last Glacial Period in Central Asia: Evidences from Aeolian Loess Sediments, Acta Geol. Sin.-Engl., 91, 1135-1136, 2017.

Sorrel, P., Oberhansli, H., Boroffka, N., Nourgaliev, D., Dulski, P., and Rohl, U.: Control of wind strength and frequency in the Aral Sea basin during the late Holocene, Quaternary Res., 67, 371382, 2007.

Stevens, T., Adamiec, G., Bird, A. F., and Lu, H. Y.: An abrupt shift in dust source on the Chinese Loess Plateau revealed through high sampling resolution OSL dating, Quaternary Sci. Rev., 82, 121-132, 2013.

Stevens, T., Buylaert, J. P., Lu, H., Thiel, C., Murray, A., Frechen, M., Yi, S., and Zeng, L.: Mass accumulation rate and monsoon records from Xifeng, Chinese Loess Plateau, based on a luminescence age model, J. Quaternary Sci., 31, 391-405, 2016.

Sun, D. H., Bloemendal, J., Rea, D. K., Vandenberghe, J., Jiang, F. C., An, Z. S., and Su, R. X.: Grain-size distribution function of polymodal sediments in hydraulic and aeolian environments, and numerical partitioning of the sedimentary components, Sediment. Geol., 152, 263-277, 2002.

Sun, D. H., Chen, F. H., Bloemendal, J., and Su, R. X.: Seasonal variability of modern dust over the Loess Plateau of China, J. Geophys. Res.-Atmos., 108, 4665, https://doi.org/10.1029/2003JD003382, 2003.

Sun, D. H., Bloemendal, J., Rea, D. K., An, Z. S., Vandenberghe, J., Lu, H. Y., Su, R. X., and Liu, T. S.: Bimodal grain-size distribution of Chinese loess, and its palaeoclimatic implications, Catena, 55, 325-340, 2004.

Sun, Y., Lu, H., and An, Z.: Grain size distribution of quartz isolated from Chinese loess/paleosol, Chinese Sci. Bull., 45, 2296-2298, 2000.

Sun, Y., Lu, H. Y., and An, Z. S.: Grain size of loess, palaeosol and Red Clay deposits on the Chinese Loess Plateau: Significance for understanding pedogenic alteration and palaeomonsoon evolution, Palaeogeogr. Palaeocl., 241, 129-138, 2006.

Sun, Y., Clemens, S. C., Morrill, C., Lin, X., Wang, X., and An, Z.: Influence of Atlantic meridional overturning circulation on the East Asian winter monsoon, Nat. Geosci., 5, 46-49, 2012.

Sun, Y. B., Wang, X. L., Liu, Q. S., and Clemens, S. C.: Impacts of post-depositional processes on rapid monsoon signals recorded by the last glacial loess deposits of northern China, Earth Planet. Sc. Lett., 289, 171-179, 2010.

Terhorst, B., Ottner, F., and Wriessnig, K.: Weathering intensity and pedostratigraphy of the Middle to Upper Pleistocene loess/palaeosol sequence of Wels-Aschet (Upper Austria), Quatern. Int., 265, 142-154, 2012.

Tsoar, H. and Pye, K.: Dust Transport and the Question of Desert Loess Formation, Sedimentology, 34, 139-153, 1987.

Ujvari, G., Kok, J. F., Varga, G., and Kovacs, J.: The physics of wind-blown loess: Implications for grain size proxy interpretations in Quaternary paleoclimate studies, Earth-Sci. Rev., 154, 247-278, 2016.

Vandenberghe, J.: Grain size of fine-grained windblown sediment: A powerful proxy for process identification, Earth-Sci. Rev., 121, 18-30, 2013.

Vandenberghe, J., Renssen, H., van Huissteden, K., Nugteren, G., Konert, M., Lu, H. Y., Dodonov, A., and Buylaert, J. P.: Pen- etration of Atlantic westerly winds into Central and East Asia, Quaternary Sci. Rev., 25, 2380-2389, 2006.

Vandenberghe, J., French, H. M., Gorbunov, A., Marchenko, S., Velichko, A. A., Jin, H., Cui, Z., Zhang, T., and Wan, X.: The Last Permafrost Maximum (LPM) map of the Northern Hemisphere: permafrost extent and mean annual air temperatures, 25 $17 \mathrm{ka} \mathrm{BP}$, Boreas, 43, 652-666, 2014.

Varga, G.: Similarities among the Plio-Pleistocene terrestrial aeolian dust deposits in the World and in Hungary, Quatern. Int., 234, 98-108, 2011.

Vriend, M.: Lost in loess: Late Quaternary eolian dust dispersal patterns across Central China inferred from decomposed loess grain-size records, 2007, PhD, Thesis, Amsterdam, VU University, the Netherlands, 53 pp., 2007.

Vriend, M. and Prins, M. A.: Calibration of modelled mixing patterns in loess grain-size distributions: an example from the northeastern margin of the Tibetan Plateau, China, Sedimentology, 52, 1361-1374, 2005.

Vriend, M., Prins, M. A., Buylaert, J. P., Vandenberghe, J., and Lu, H. Y.: Contrasting dust supply patterns across the north-western Chinese Loess Plateau during the last glacial-interglacial cycle, Quatern. Int., 240, 167-180, 2011.

Wang, H., Mason, J. A., and Balsam, W. L.: The importance of both geological and pedological processes in control of grain size and sedimentation rates in Peoria Loess, Geoderma, 136, 388-400, 2006.

Weltje, G. J.: Endmember modeling of compositional data: numerical-statistical algorithms for solving the explicit mixing problem, Math. Geol., 29, 503-549, 1997.

Weltje, G. J. and Prins, M. A.: Genetically meaningful decomposition of grain-size distributions, Sediment. Geol., 202, 409-424, 2007.

Wolff, C., Plessen, B., Dudashvilli, A. S., Breitenbach, S. F., Cheng, H., Edwards, L. R., and Strecker, M. R.: Precipitation evolution of Central Asia during the last 5000 years, Holocene, 27, 142154, 2017.

Xiao, J., Porter, S. C., An, Z. S., Kumai, H., and Yoshikawa, S.: Grain-Size of Quartz as an Indicator of Winter Monsoon Strength on the Loess Plateau of Central China during the Last 130,000Yr, Quaternary Res., 43, 22-29, 1995.

Yang, F., Zhang, G. L., Yang, F., and Yang, R. M.: Pedogenetic interpretations of particle-size distribution curves for an alpine environment, Geoderma, 282, 9-15, 2016.

Yang, S. L. and Ding, Z. L.: Advance-retreat history of the EastAsian summer monsoon rainfall belt over northern China during the last two glacial-interglacial cycles, Earth Planet. Sc. Lett., 274, 499-510, 2008.

Yang, S. L. and Ding, Z. L.: A $249 \mathrm{kyr}$ stack of eight loess grain size records from northern China documenting millennial-scale climate variability, Geochem. Geophy. Geosy., 15, 798-814, https://doi.org/10.1002/2013GC005113, 2014.

Yang, S. L., Ding, F., and Ding, Z. L.: Pleistocene chemical weathering history of Asian arid and semi-arid regions recorded in loess deposits of China and Tajikistan, Geochim. Cosmochim. Ac., 70, 1695-1709, 2006.

Youn, J. H., Seong, Y. B., Choi, J. H., Abdrakhmatov, K., and Ormukov, C.: Loess deposits in the northern Kyrgyz Tien Shan: Implications for the paleoclimate reconstruction during the Late Quaternary, Catena, 117, 81-93, 2014. 
Yu, S. Y., Colman, S. M., and Li, L. X.: BEMMA: A Hierarchical Bayesian End-Member Modeling Analysis of Sediment GrainSize Distributions, Math. Geosci., 48, 723-741, 2016.

Zech, R.: A late Pleistocene glacial chronology from the KitschiKurumdu Valley, Tien Shan (Kyrgyzstan), based on Be-10 surface exposure dating, Quaternary Res., 77, 281-288, 2012.

Zeeden, C., Hambach, U., Veres, D., Fitzsimmons, K., Obreht, I., Bösken, J., and Lehmkuhl, F.: Millennial scale climate oscillations recorded in the Lower Danube loess over the last glacial period, Palaeogeogr. Palaeocl., https://doi.org/10.1016/j.palaeo.2016.12.029, 2016.

Zhang, X. J., Jin, L. Y., Huang, W., and Chen, F. H.: Forcing mechanisms of orbital-scale changes in winter rainfall over northwestern China during the Holocene, Holocene, 26, 549-555, 2016.
Zhang, X. Y., Arimoto, R., and An, Z. S.: Glacial and interglacial patterns for Asian dust transport, Quaternary Sci. Rev., 18, 811819, 1999.

Zhao, L., Jin, H., Li, C., Cui, Z., Chang, X., Marchenko, S. S., Vandenberghe, J., Zhang, T., Luo, D., and Guo, D.: The extent of permafrost in China during the local Last Glacial Maximum (LLGM), Boreas, 43, 688-698, 2014.

Zhou, L. P., Oldfield, F., Wintle, A. G., Robinson, S. G., and Wang, J. T.: Partly Pedogenic Origin of Magnetic Variations in Chinese Loess, Nature, 346, 737-739, 1990. 